\title{
Highly Sensitive Detection of Cancer Antigen 15-3 Using Novel Avian IgY Antibodies
}

Renata Grzywa ${ }^{1}$, Agnieszka Łupicka-Słowik ${ }^{1}$, Maciej Walczak ${ }^{1}$, Magdalena Idzi ${ }^{1}$, Kamila Bobrek ${ }^{2}$, Stephane Boivin ${ }^{3}$, Andrzej Gawet' ${ }^{2}$,Tadeusz Stefaniak ${ }^{4}$, Józef Oleksyszyn ${ }^{1}$, and Marcin Sieńczyk ${ }^{1}$

${ }^{1}$ Wroclaw University of Technology, Faculty of Chemistry, Division of Medicinal Chemistry and Microbiology, Wroclaw, Poland;

${ }^{2}$ Wroclaw University of Environmental and Life Sciences, Faculty of Veterinary Medicine, Department of Epizootiology and Clinic of Bird and Exotic Animals, Wroclaw, Poland; ${ }^{3}$ European Molecular Biology Laboratory (EMBL), Hamburg, Germany;

${ }^{4}$ Wroclaw University of Environmental and Life Sciences, Faculty of Veterinary Medicine, Department of Immunology,

Pathophysiology and Veterinary Preventive Medicine, Wroclaw, Poland

\begin{abstract}
Summary
Early detection of cancer development is crucial for successful therapy and for monitoring patient outcome. Various immunodiagnostic methods are able to detect pathological changes in the human body ahead of symptomatic manifestation of the disease. Most immunological examinations are based on the detection of specific tumor markers in body fluids. Of the various cancer-specific proteins used for breast cancer diagnostics, one of the most commonly applied is the cancer antigen 15-3 (CA 15-3). An elevation in its serum level (>25-40 U/ml) usually correlates with tumor malignancy. The CA 15-3 antigen is also used for monitoring patients after surgical treatment and for measuring therapeutic efficacy. Herein, we present the generation of polyclonal IgY antibodies isolated from egg yolks of immunized hens and their application for CA 15-3 detection. The developed sandwich ELISA assay showed a detection limit of $0.028 \mathrm{U} / \mathrm{ml}$, thus demonstrating its potential for clinical applications.
\end{abstract}

Keywords: IgY antibody, breast cancer, CA 15-3 antigen, ELISA

\section{Introduction}

Due to the popularization of breast cancer screening and the development of novel diagnostic methods and therapeutic approaches, the death rate caused by breast cancer has been reduced over the last two decades in the US and a few other developed countries. However, breast cancer is still the main cause of cancer death among women, with approximately 1.4 million new cases and nearly 0.5 million deaths worldwide per year (American Cancer Society, 2011).

Breast cancer originates in breast tissue (lobules and ducts) and usually remains asymptomatic at early stages of development. A small, localized breast tumor can be diagnosed early by mammography, physical examination, or magnetic resonance imaging. Unfortunately, only a small percentage of diagnosed tumors are non-invasive, whereas the majority is capable of spreading into the surrounding tissues (Nothacker et al., 2009). Tumor size and malignancy are the main prognostic factors for the prediction of cancer patient outcome (Michaelson et al., 2003). Depending on the stage, for most cases, the treatment includes surgical intervention, usually associated with chemother- apy, radiation, or hormone therapy. Post-operative surveillance and the monitoring of disease metastasis rely on the detection of specific serum markers, such as CA 15-3, CEA, or TPA; however, these markers should be combined with imaging methods. In spite of the moderate sensitivity and the limited applicability to advanced breast cancer, monitoring serum marker levels can indicate metastatic disease several months before clinical symptoms (Cheung et al., 2009; Duffy, 2006).

Mucin 1 (MUC1) is a transmembrane glycoprotein expressed on the surface of many epithelial cells of the breast, bladder, kidney, stomach, liver, or respiratory tract (Hanisch and Müller, 2000). The molecular weight of MUC1 is approximately 300-600 $\mathrm{kDa}$; sugars constitute 50 to $80 \%$ of MUC1, and the glycosylation level can vary depending on the tissue from which it originates (Singh and Bandyopadhyay, 2007). In contrast to normal cells, cancer cells lose the apical orientation of MUC1, its content in the membrane is increased, and the glycosylation pattern is altered (Hanisch and Müller, 2000). CA 15-3 is a soluble form of MUC1, and its elevation can be detected in the serum of breast cancer patients, especially those with metastatic disease. However, an increased level of CA 15-3 can also be associated with pancreatic

Received September 18, 2013; accepted in revised form November 19, 2013; Epub November 19, 2013; http://dx.doi.org/10.14573/altex.1309181

Abbreviations: BSA, bovine serum albumin; CA 15-3, cancer antigen 15-3; CEA, carcinoembrionic antigen; DCM, dichloromethane; DIPEA, N,N-diisopropylethylamine; DMF, dimethylformamide; GMBS, $N$ - $\gamma$-maleimidobutyryl-oxysuccinimide ester; HAMA, human anti-mouse antibody; $\mathrm{HOBt}$, hydroxybenzotriazole; HRP, horseradish peroxidase; $\mathrm{KLH}$, keyhole limpet hemocyanin; mmlgG, mouse monoclonal immunoglobulin G; MUC1, mucin 1; OPD, o-phenylenediamine; PyBOP, benzotriazol-1-yl-oxytripyrrolidinophosphonium hexafluorophosphate; TFA, trifluoroacetic acid; TPA, tissue polypeptide antigen 
(Deguchi et al., 2010), lung, ovary, endometrial, bladder, or gastrointestinal carcinomas (Cheung et al., 2009; Duffy et al., 2010). Additionally, a moderately elevated CA 15-3 serum level may be observed in benign breast tumors and other diseases, such as liver cirrhosis, chronic hepatitis, systemic lupus erythematosus, sarcoidosis, tuberculosis, megaloblastic anemia, and hypothyroidism (Cheung et al., 2009; Duffy et al., 2010). On the other hand, for breast cancer patients at the early stage of disease development, the measurement of serum CA 15-3 levels lacks sensitivity and is therefore not recommended for screening, staging, or preoperative diagnosis. In contrast, CA 15-3 measurements are highly valuable for monitoring the effectiveness of therapy for patients with metastatic breast cancer, where changes in serum marker levels indicate the response to therapy. Although the determination of CA 15-3 levels during postoperative surveillance can indicate recurrent disease with a lead time of 5-6 months, it is unclear if therapy based on CA 15-3 detection improves patient outcome. Despite all its limitations, CA 15-3 is still the most widely used and investigated of all known serum markers in breast cancer diagnostics (Duffy, 2006; Duffy et al., 2010).

The first radioimmunometric assay for CA 15-3 was introduced almost 30 years ago and was based on two monoclonal antibodies: DF3 (raised by mouse immunization using the membrane-enriched fraction of metastatic human breast cancer) (Hayes et al., 1985) and 115D8 (generated after mouse challenge with the membrane of human milk fat globules) (Cheung et al., 2009; Kallioniemi et al., 1988). The most commonly used assays for detecting CA 15-3 are based on sandwich ELISA with 115D8 (used as a capture antibody) and DF3 (as a detecting antibody); these assays are still considered the "gold" standard for breast cancer diagnostics (Klee and Schreiber, 2004). The cutoff value for the serum CA 15-3 level is defined between 25 and $40 \mathrm{U} / \mathrm{ml}$ (Duffy et al., 2010).

IgY antibodies are an element of the humoral immune system of birds, reptiles, and amphibians. As the evolutionary ancestor of mammalian $\mathrm{IgG}$ and $\mathrm{IgE}$ antibodies, $\mathrm{IgY}$ antibodies share many structural and functional features and therefore have been successfully used in many applications (Warr et al., 1995). The diagnostic potential of IgY antibodies is the result of their lack of reactivity with human rheumatoid factor, HAMA, and the complement system (Schade et al., 2005). Thus, the application of IgYs allows a decrease in the number of false positive results when compared with serological assays based on mammalian detection systems (Schade and Hlinak, 1996). Specific IgY antibodies can be isolated relatively easily from egg yolks of immunized hens with yields of up to $10 \mathrm{mg} / \mathrm{egg}$ (total $\mathrm{IgY}$ isolation yield can reach up to $100 \mathrm{mg} / \mathrm{egg}$ ) (Da Silva and Tambourgi, 2010). Additionally, hen immunization evokes an immune response manifested by the production of antigen specific IgY antibodies, usually throughout the animal lifetime (Svendsen Bollen et al., 1996). Therefore, considering the low cost of production, high isolation yields, and ethical aspects (the IgY antibodies are isolated from egg yolk, which significantly reduces the animals' suffering), IgY represents an attractive alternative to mammalian IgGs for diagnostic and research applications (Da Silva and Tambourgi, 2010; Narat, 2003; Xiao et al., 2009). Several studies explored the utility of IgY antibodies for breast cancer diagnostics, where antigen-specific antibodies were raised against thymidine kinase 1 (He et al., 2006; Huang et al., 2012), estrogen receptor $\beta$ (Esslimani-Sahla et al., 2005), psoriasin (Al-Haddad et al., 1999), uPA, and tPA (Grebenschikov et al., 1997).

In this study, we focused our attention on the generation of a specific IgY antibody against the native CA 15-3 protein and against two selected CA 15-3 peptidyl epitopes; these epitopes were conjugated to carrier proteins (KLH and BSA) and were then used for immunization. The immunochemical analysis of an isolated IgY antibody includes the determination of the titer, avidity, and antigen detection limit as well as the cross-reactivity with the native CA 15-3 protein of the epitope-specific IgY antibodies. Additionally, the development of an $\mathrm{IgG} / \mathrm{IgY}$ sandwich ELISA for the CA 15-3 detection showed the diagnostic potential of the generated IgY antibody.

\section{Materials, methods, and animals}

\subsection{Computer-assisted epitope prediction}

The model of the CA 15-3 protein 3D structure was generated using an automated protein modeling server - SWISS-MODEL (http://swissmodel.expasy.org; Arnold et al., 2006). The sequence of human mucin 1 was used as a template for the homology modeling (UniProt: P15941). Swiss-Model allowed the generation of homology models based on the NMR solution structure of the human mucin 1 SEA domain (PDB: 2ACM; Macao et al., 2006). The sequence fragments for the obtained models were identical to the template structure and were composed of amino acid residues 1041 to 1097 and 1098 to 1144 . To determine the water accessibility as well as the electrostatic potential surface, the CA 15-3 models were analyzed using PyMol (The PyMOL Molecular Graphics System, Version 1.5.0.4 Schrödinger, LLC) and Delphi software (Li et al., 2012). Subsequently the $\alpha$-helical tendencies of selected sequences in solution were investigated using the Agadir algorithm (Muňoz and Serrano, 1997). On the basis of the obtained data, two polypeptide fragments that might adopt native conformation in solution, independent of the rest of the structure, were selected. The selected sequences were further optimized by adding flanking residues to obtain relatively short sequences with all of the residues that are crucial for structure stabilization.

\subsection{Antigen preparation}

Highly purified human cancer antigen 15-3 (CA 15-3) isolated from the human BTA cell line was purchased from a commercial source (Fitzgerald, Acton, MA, USA). The protein was dialyzed against PBS ( $\mathrm{pH}$ 7.4) prior to immunization and stored at $-20^{\circ} \mathrm{C}$ until use. A commercial CA 15-3 assay (Labor Diagnostika Nord $\mathrm{GmbH} \& \mathrm{Co} \mathrm{KG}$, Zory, Poland) was used to measure the CA 15-3 concentration $(\mathrm{U} / \mathrm{ml})$. The selected peptidyl fragments of CA 15-3 protein were synthesized in house using a solid-phase peptide synthesis method. Briefly, the resins (H-L-Gly-2-Cl-Trt resin, $0.75 \mathrm{mmol} / \mathrm{g}$; H-L-Leu-2-Cl-Trt resin, $0.79 \mathrm{mmol} / \mathrm{g}$; IRIS Biotech $\mathrm{GmbH}$, Marktredwitz, Germany) were washed in DCM, DCM/DMF $(1: 1, v / v)$ and then swollen in DMF for $1 \mathrm{~h}$. Subsequently Fmoc-protected amino ac- 
ids (3 eq.) in DMF as well as PyBOP (3 eq.), HOBt (3 eq.), and DIPEA (6 eq.) were added to the resin. The Keiser test was used to monitor the progress of coupling reactions. After the reaction was complete, the resin was washed with DMF, which was followed by the Fmoc deprotection using a $20 \%$ solution of piperidine in DMF. After washing, the same coupling procedure was repeated for all subsequent Fmoc-protected amino acids. N-terminal Cys residues were introduced into both peptides to provide the sulfhydryl groups used for further conjugation with carrier proteins. The peptide complete deprotection step with simultaneous cleavage from the resin was performed using a TFA:triisopropylsilane:1,2-ethanedithiol:phenol (95:2.5:2.5:5, $v / v)$ solution. All Fmoc-protected amino acids, coupling reagents, and solvents used for peptide synthesis were supplied by IRIS Biotech GmbH, Marktredwitz, Germany. Both synthesized peptidyl epitopes (CA15-3(1066-1085): CYQELQRDISEMFLQIYKQGG, corresponding to residues 1066-1085 and CA 15-3(1085-1103): CGFLGLSNIKFRPGSVVVQL, corresponding to residues 10851103) were purified by HPLC (SunFire ${ }^{\mathrm{TM}}$ Prep C8 column, $10 \mathrm{x}$ $250 \mathrm{~mm}, 5 \mu \mathrm{m}$, Sigma-Aldrich, Poland) to homogeneity, and their molecular weight was confirmed by high resolution mass spectrometry (Waters Acquity Ultra Performance LC, LCT Premier $\mathrm{XE}$ ) yielding: CA 15-3(1066-1085) (observed $\mathrm{m} / \mathrm{z}, 1275.6160$ and 850.4250; calculated 1275.6138 $(\mathrm{M}+2)^{2+}$ and $850.4108(\mathrm{M}+3)^{3+}$ for $\mathrm{C}_{112} \mathrm{H}_{173} \mathrm{~N}_{29} \mathrm{O}_{35} \mathrm{~S}_{2}$ ) and CA 15-3(1085-1103) (observed $\mathrm{m} / \mathrm{z}$, 1067.5848 and 712.4333; calculated $1067.5963(\mathrm{M}+2)^{2+}$ and $712.4011(\mathrm{M}+3)^{3+}$ for $\left.\mathrm{C}_{98} \mathrm{H}_{160} \mathrm{~N}_{26} \mathrm{O}_{25} \mathrm{~S}\right)$. The peptides were freezedried and stored at $-20^{\circ} \mathrm{C}$ for further use.

The peptide-carrier conjugates used for immunization as well as for immunochemical analyses were prepared with keyhole limpet hemocyanin from Megathura crenulata (KLH; Pierce, Gdansk, Poland) and bovine serum albumin (BSA; Sigma-Aldrich, Poznan, Poland) using $N$ - $\gamma$-maleimidobutyryloxysuccinimide ester (GMBS; synthesized in-house) as a heterobifunctional crosslinking agent. In the first step, the carrier protein (KLH or BSA) dissolved in PBS was activated with GMBS followed by a $2 \mathrm{~h}$ incubation at room temperature with gentle shaking. Unreacted crosslinking reagent was removed using gel filtration (10DG column, BioRad, Warsaw, Poland) and peptide (CA 15-3(1066-1085) or CA 15-3(1085-1103)) dissolved in PBS was added to the maleimide-activated carrier protein. The reaction was performed at room temperature for $3 \mathrm{~h}$ with gentle agitation, and its progress was monitored by HPLC. After the reaction was completed, the conjugates were aliquoted, freeze-dried, and stored at $-80^{\circ} \mathrm{C}$ until use. The molar peptide/carrier ratios determined by HPLC were as follows: $720 \mathrm{~mol} / \mathrm{mol}$ (KLH-CA 15-3(1066-1085)), $2206 \mathrm{~mol} / \mathrm{mol}$ (KLH-CA 15-3(1085-1103)), 2.9 mol/mol (BSA-CA 15-3(1066$1085)$ ), and $4.5 \mathrm{~mol} / \mathrm{mol}$ (BSA-CA 15-3(1085-1103)).

\subsection{Animals}

All experiments were conducted in accordance with protocols approved by the II Local Ethics Committee for Animal Experiments of the Wroclaw University of Environmental and Life Sciences in Wroclaw, Poland (Permit Number: 52/2010) and were in compliance with local, national as well as with the ARRIVE guidelines (Kilkenny et al., 2010). Animals were monitored for any signs of distress and pain. White Leghorn laying hens, 20 weeks of age, were purchased commercially (Wozniak Poultry Farm, Zylice, Poland) and were allowed to adapt to the housing conditions for 14 days prior to immunization. The animals were housed in a room that was lighted for $14 \mathrm{~h}$ per day at a maintained temperature of $25 \pm 2^{\circ} \mathrm{C}$ in well-ventilated cages (floor area: $2000 \mathrm{~cm}^{2}$, height: 45 $\mathrm{cm}$; two hens per cage) in the Vivarium of the Wroclaw University of Environmental and Life Sciences, Faculty of Veterinary Medicine (Wroclaw, Poland), and the animals were provided with full access to food (Cargill, Wroclaw, Poland) and water ad libitum.

\subsection{Hen immunization}

All antigens were dissolved in $150 \mu \mathrm{l}$ of $0.9 \%$ saline (Baxter, Warsaw, Poland) and emulsified with an equal volume of Freund's complete adjuvant (MP Biomedicals, Solon, OH, USA). Hens were randomly divided into groups of four and immunized intramuscularly (Musculus pectoralis, left and right) at two different sites with $150 \mu \mathrm{l}$ per side. The antigens were used in the amounts of $100 \mu \mathrm{g}$ per animal for the native CA 15-3 protein (group I), KLH-CA 15-3(1085-1103) (group II), and BSA-CA 15-3(1066-1085) (group III), and $150 \mu \mathrm{g}$ for KLHCA 15-3(1066-1085) (group IV). The control group received only an emulsion of $0.9 \%$ saline with Freund's complete adjuvant. For peptide-carrier conjugates, the amount of antigen was calculated for the peptide content. All groups were subjected to two booster injections. For group I and II, booster doses were administered 4 and 12 weeks after the first immunization with half of the initial dose of the antigen. For groups III and IV, boosters were injected after 2 and 6 weeks with an amount of antigen equivalent to the initial dose. For booster injections, incomplete Freund's adjuvant (Sigma-Aldrich, Poznan, Poland) was used. Eggs were collected daily from the first day of immunization and stored at $4^{\circ} \mathrm{C}$ before isolation.

The reason for including the BSA-CA 15-3(1066-1085) conjugate in the present study as well as the higher dose of KLH-CA 15-3(1066-1085) conjugate was to evaluate the effect of the carrier protein on the specific antibody production and the effect of the administered dose because the immunization with $100 \mu \mathrm{g} /$ hen of KLH-CA 15-3(1066-1085) resulted in a low epitope-specific IgY antibody response (data not shown).

\subsection{IgY antibody isolation}

The isolation procedure described by Polson et al. (1980) was applied with minor modifications. Eggs were washed with 50\% isopropanol before the yolk was separated from the white. To remove the remaining white, the yolk was rolled on a paper towel, the yolk sac was pierced, and the content was transferred into a $50 \mathrm{ml}$ tube. The yolk was diluted 5-fold with a $4.375 \%$ solution of polyethylene glycol 6000 (AppliChem, Gdansk, Poland) in PBS (final PEG 6000 concentration was $3.5 \%$ ) and was then thoroughly mixed and centrifuged at $4750 \times \mathrm{g}$ for $15 \mathrm{~min}\left(4^{\circ} \mathrm{C}\right)$. Next, solid PEG 6000 was added to the filtered supernatant to a final concentration of $12 \%$ and was mixed until completely dissolved followed by centrifugation as before. The supernatant was discarded, and the precipitate was dissolved in $10 \mathrm{ml}$ of PBS followed by the addition of $1.2 \mathrm{~g}$ of PEG 6000. The mixture was stirred until PEG 6000 was completely dissolved, and the mixture was then centrifuged as before. The obtained precipitate containing IgY antibodies was dissolved in $5 \mathrm{ml}$ of PBS and stored at $-20^{\circ} \mathrm{C}$. 
The purity of the isolated $\operatorname{IgY}$ antibodies was verified by SDS PAGE (4-12\%, Tris-glycine) under nonreducing conditions followed by Coomassie blue R250 staining (Calbiochem, Warsaw, Poland). The concentration of the IgY antibody isolates was examined using a Coomassie PLUS assay (Pierce, Gdansk, Poland). The IgY antibodies used in the ELISA assays were further purified by gel filtration using a Sephadex G-100 (GE Healthcare, Warsaw, Poland) and following the manufacturer's protocol.

\subsection{Immunoanalysis}

Antigen-specific response during the course of immunization and avidity maturation (ELISA)

The production of antigen-specific IgY antibodies by hens during the time of immunization was examined by ELISA. For this purpose, 96-well microtiter plates (MaxiSorp, Nunc, Gdansk, Poland) were coated with $100 \mu \mathrm{l}$ of the antigen $(500 \mathrm{ng} / \mathrm{ml}$; the amount of antigen used for analysis of the epitope-specific IgY antibodies was calculated for the peptide content) in $50 \mathrm{mM}$ sodium carbonate buffer ( $\mathrm{pH} 9.6$ ) overnight at $4^{\circ} \mathrm{C}$ in a wet chamber. To eliminate the signal resulting from anti-carrier antibodies in the sample, isolated IgY antibodies raised by immunization with KLH-peptide conjugates were analyzed using BSApeptide constructs, whereas the KLH-peptide conjugate was used to analyze the $\operatorname{IgY}$ antibodies raised by immunization with the BSA-peptide. The plates were washed three times with PBS containing $0.05 \%$ Tween-20 at $\mathrm{pH} 7.4$ (PBST) followed by blocking of non-specific sites with $10 \%$ skim milk in PBS for $2 \mathrm{~h}$ at $37^{\circ} \mathrm{C}$ in a wet chamber and washing as before. All washing steps were performed using an automated ELISA plate washer (Combiwash, HUMAN, Gdansk, Poland). Subsequently, $100 \mu 1$ of antigen-specific or control IgY antibodies (1:100) in $0.5 \%$ skim milk in PBST were added and incubated for $1 \mathrm{~h}$ at $37^{\circ} \mathrm{C}$ in a wet chamber. The plates were washed and incubated $\left(1 \mathrm{~h}, 37^{\circ} \mathrm{C}\right)$ with $100 \mu \mathrm{l} /$ well of rabbit anti-IgY-HRP conjugate (Pierce, Gdansk, Poland) diluted in $0.5 \%$ skim milk in PBST (1:5000). The plates were washed, and $100 \mu 1$ of $O$-phenylenediamine solution (OPD; Pierce, Gdansk, Poland) in $50 \mathrm{mM}$ citrate buffer with $0.015 \% \mathrm{H}_{2} \mathrm{O}_{2}$ at $\mathrm{pH} 5.0$ was added. The reaction was terminated with $1 \mathrm{M} \mathrm{H}_{2} \mathrm{SO}_{4}(50 \mu \mathrm{l})$, and the absorbance was measured at $490 \mathrm{~nm}$ using a microplate reader (Multiskan FC, Thermo Scientific, Poland). The results are expressed as the OD490* values after the subtraction of the values obtained for the control IgY antibodies.

The avidity maturation of the IgY antibodies was examined by ELISA in similar fashion as described above, with the exception that before addition of HRP-labeled secondary antibody, the wells were incubated with $100 \mu 1$ of $6 \mathrm{M}$ urea/PBST solution (10 min, RT) or with PBST. After washing, the plates were developed using OPD as the chromogenic substrate. The results are expressed as the OD490* values after the subtraction of the values obtained for the control IgY antibodies.

\section{Titration of IgY antibodies by ELISA}

To examine the titer of the obtained antigen-specific IgY antibodies, a 96-well microtiter plate was coated with target antigen as described previously. After washing with PBST, the plates were incubated with serially diluted specific or control IgY antibodies (100 $\mu \mathrm{l} /$ well in $0.5 \%$ skim milk in PBST) within the range of
$10-0.0025 \mu \mathrm{g} / \mathrm{ml}$ for anti-CA 15-3 IgY antibodies, 100-0.25 $\mu \mathrm{g} /$ $\mathrm{ml}$ for anti-CA 15-3(1066-1085) IgY antibodies, and 50-0.025 $\mu \mathrm{g} / \mathrm{ml}$ for anti-CA 15-3(1085-1103) IgY antibodies. The dilution range for the control $\mathrm{IgY}$ antibodies was prepared as for the antigen-specific IgY antibodies. The following steps were performed as described before. All measurements were performed in duplicate. The results are expressed as an ELISA Index (EI), where $\mathrm{EI}=\mathrm{OD}_{\text {sample }} / \mathrm{OD}_{\text {control}}$, and values of $\mathrm{EI}>1.2$ were considered positive (Silva et al., 2002).

\section{Antigen detection limit (ELISA)}

The antigen detection limit using the generated IgY antibodies was examined by ELISA as described before. For this purpose, 96-well plates were coated with the target antigen $(50 \mathrm{mM}$ sodium carbonate buffer, $\mathrm{pH} 9.6$, overnight, $4^{\circ} \mathrm{C}$ ) within the concentration range of $1 \mu \mathrm{g} / \mathrm{ml}-0.5 \mathrm{ng} / \mathrm{ml}$ for CA $15-3$ and CA 15-3(1085-1103) (calculated for the peptide content) and $5 \mu \mathrm{g} / \mathrm{ml}-5 \mathrm{ng} / \mathrm{ml}$ for KLH and BSA conjugates of CA 153(1066-1085). After washing, antigen-specific and control IgY antibodies were added at a concentration of $10 \mu \mathrm{g} / \mathrm{ml}$ for anti-CA 15-3 and anti-CA 15-3(1085-1103) IgY antibodies and $25 \mu \mathrm{g} / \mathrm{ml}$ for anti-CA 15-3(1066-1085) IgY antibodies prepared in $0.5 \%$ skim milk in PBST. The control IgY antibodies were prepared in the same manner as the antigen-specific IgY antibodies. After incubation $\left(1 \mathrm{~h}, 37^{\circ} \mathrm{C}\right.$, wet chamber $)$, the plates were washed with PBST, incubated with rabbit anti-IgY-HRP conjugate and developed as described before. The detection limit was considered to be the minimal concentration of antigen for which the EI value was greater than 1.2.

\section{CA 15-3 detection with mouse monoclonal IgG and IgY antibodies}

The reactivity of the generated anti-CA 15-3 IgY antibodies in comparison with mouse monoclonal anti-CA 15-3 IgG was examined by ELISA. For this purpose, a 96-well plate was coated with native CA $15-3$ protein in the concentration range of $5 \mu \mathrm{g}$ / $\mathrm{ml}-1 \mathrm{ng} / \mathrm{ml}$. The plate was incubated, washed, and blocked as described before. Subsequently, isolated anti-CA 15-3 IgY, mouse monoclonal anti-CA 15-3 IgG (clone A: M2012111 and clone B: M002204; Fitzgerald, Acton, MA, USA), control IgY, and control mouse IgG (Merck, Warsaw, Poland) antibodies were added (2 $\mu \mathrm{g} / \mathrm{ml}$, in $0.5 \%$ skim milk/PBST). After $1 \mathrm{~h}$ of incubation at $37^{\circ} \mathrm{C}$, the plate was washed with PBST and incubated $\left(1 \mathrm{~h}, 37^{\circ} \mathrm{C}\right)$ with secondary antibody (1:2500), i.e., rabbit anti-IgY-HRP conjugate (Pierce, Gdansk, Poland) or rabbit anti-mouse IgG-HRP conjugate (Fitzgerald, Acton, MA, USA) diluted in $0.5 \%$ skim milk in PBST. The plate was developed as described previously.

Additionally, the reactivity of the generated anti-CA 15-3 IgY antibody was compared with mouse monoclonal anti-CA 15-3 IgG by the dot blot method. For this purpose, a nitrocellulose membrane (0.45 $\mu \mathrm{m}$, Thermo Scientific, Gdansk, Poland) was coated with CA 15-3 protein in an amount ranging from $100 \mathrm{ng}$ to $0.1 \mathrm{ng}$ in PBS. The nonspecific binding sites were blocked with $5 \%$ skim milk in PBST (overnight, $4^{\circ} \mathrm{C}$ ). Next, the membrane was washed with PBST, cut into strips, and incubated with anti-CA 15-3, control IgY antibodies, mouse anti-CA 15-3 (clone A and clone B) or control mouse IgG antibodies $(2 \mu \mathrm{g} / \mathrm{ml})$ 
prepared in $0.5 \%$ skim milk/PBST $\left(1 \mathrm{~h}, 37^{\circ} \mathrm{C}\right)$. Subsequently, the strips were washed with PBST followed by incubation $(1 \mathrm{~h}$, $37^{\circ} \mathrm{C}$ ) with secondary antibody conjugates: rabbit anti-IgY-HRP (1:10,000; Fitzgerald, Acton, MA, USA) or rabbit anti-mouse IgG-HRP (1:2500; Fitzgerald, Acton, MA, USA). The strips were washed, and the signal was developed using a chemiluminescent peroxidase substrate (Super Signal West Pico, Pierce, Gdansk, Poland) and visualized with a blot imaging system (Gel Logic 1500, Carestream, Rochester, NY, USA).

\section{Cross-reactivity of epitope-raised Ig $Y$ antibodies with \\ CA 15-3 protein}

The ability of epitope-specific IgY antibodies to recognize native CA 15-3 protein was examined by ELISA and dot blot. For the ELISA assay, a 96-well microtiter plate was coated with $100 \mu \mathrm{l} /$ well of CA 15-3 protein within the concentration range of $5 \mu \mathrm{g} / \mathrm{ml}$ - $10 \mathrm{ng} / \mathrm{ml}$ and incubated overnight at $4^{\circ} \mathrm{C}$ in a wet chamber. The plate was washed and blocked as described previously followed by incubation $\left(1 \mathrm{~h}, 37^{\circ} \mathrm{C}\right)$ with $50 \mu \mathrm{g} / \mathrm{ml}$ for anti-CA $15-3(1085$ 1103), anti-CA 15-3(1066-1085) raised by immunization with BSA-CA 15-3(1066-1085) conjugate or control IgY antibodies. The following steps were performed as described before.

For dot blot analysis, the nitrocellulose membrane was coated with CA 15-3 protein within the concentration range of $500 \mathrm{ng}$ - 5 ng in PBS, blocked, and washed, as described previously. The strips were subsequently incubated with epitope-specific or control IgY antibodies $(100 \mu \mathrm{g} / \mathrm{ml}$, in $0.5 \%$ skim milk/PBST, 1 $\left.\mathrm{h}, 37^{\circ} \mathrm{C}\right)$. The incubation with secondary rabbit anti-IgY-HRP conjugate and the signal detection were performed as described above.

\subsection{Detection of CA 15-3 antigen by sandwich ELISA}

For the detection of the CA 15-3 protein by sandwich ELISA, mouse monoclonal anti-CA 15-3 IgG (clone A: M2012111; Fitzgerald, Acton, MA, USA) was used as a capture antibody and generated polyclonal anti-CA 15-3 IgY as a secondary antibody. For that purpose, a 96-well plate was coated with the capture antibody $(2 \mu \mathrm{g} / \mathrm{ml}, 50 \mathrm{mM}$ sodium carbonate buffer, $\mathrm{pH} 9.6)$ and incubated overnight at $4^{\circ} \mathrm{C}$ in a wet chamber. The plate was then washed three times in PBST and blocked in $10 \%$ skim milk in PBS $\left(2 \mathrm{~h}, 37^{\circ} \mathrm{C}\right)$. The plate was washed and incubated $(1 \mathrm{~h}$, $37^{\circ} \mathrm{C}$ ) with a serial dilution of CA $15-3$ protein within the range of $500 \mathrm{ng} / \mathrm{ml}-0.5 \mathrm{ng} / \mathrm{ml}$. Subsequently, the plate was washed in PBST and incubated $\left(1 \mathrm{~h}, 37^{\circ} \mathrm{C}\right)$ with $10 \mu \mathrm{g} / \mathrm{ml}$ of anti-CA $15-3$ IgY antibody in $0.5 \%$ skim milk in PBST. After washing, rabbit anti-IgY-HRP conjugate (1:5000) was added and incubated for $1 \mathrm{~h}$ in $37^{\circ} \mathrm{C}$. The reaction was developed with OPD and terminated with $1 \mathrm{M} \mathrm{H}_{2} \mathrm{SO}_{4}$, as described previously.

\subsection{Data analysis}

All data were analyzed using GraphPad Prism version 5.0 software (GraphPad Software Inc., La Jolla, CA, USA). The results are presented as the mean \pm SEM of experiments performed in duplicate. The statistical significance $(\mathrm{p}<0.005)$ of the antigenspecific response during the time of immunization was evaluated using a 2-tailed $t$-test.

\section{Results}

\subsection{Egg-yolk antibody production}

Animals were immunized either with native CA 15-3 protein or its selected epitope fragments conjugated with BSA and KLH carrier proteins. The immunizations were well tolerated by the animals, and the experiment was conducted over the course of 20 weeks. The IgY antibodies were isolated from every collected egg yolk. The isolation procedure was based on the PEG 6000 precipitation method previously described by Polson et al. (1980). The IgY isolates obtained by the application of this method displayed a purity of $85-90 \%$ (Fig. 1). The average isolation yield was approximately $90 \mathrm{mg}$ per yolk. For ELISA analysis, isolated IgY antibodies were further purified using gel filtration on a Sephadex G-100. The isolated antibodies were stored at $-20^{\circ} \mathrm{C}$ for several months with no detectable loss of activity.

\subsection{Specific IgY antibody production and avidity maturation}

The reactivity of antigen-specific IgY antibodies and the maturation of their avidity during the time of immunization were monitored by indirect ELISA. The obtained data showed that for animals challenged with native CA 15-3 antigen, the production of specific IgY antibodies was detectable from the fourth week of immunization, and its level remained stable throughout the entire immunization period. Anti-CA 15-3 IgY antibodies of high avidity appeared six weeks after the initial immunization (Fig. 2A).

Epitope-specific IgY antibodies raised by immunization with KLH conjugates of CA 15-3 fragments (CA 15-3(1066-1085) and CA 15-3(1085-1103)) were observed 5 weeks after the first immunization. However, some differences in the immune response between these two groups were observed. The reactivity as well as the avidity of the anti-CA 15-3(1085-1103) IgY antibodies were constant after the epitope-specific immunity had been elicited

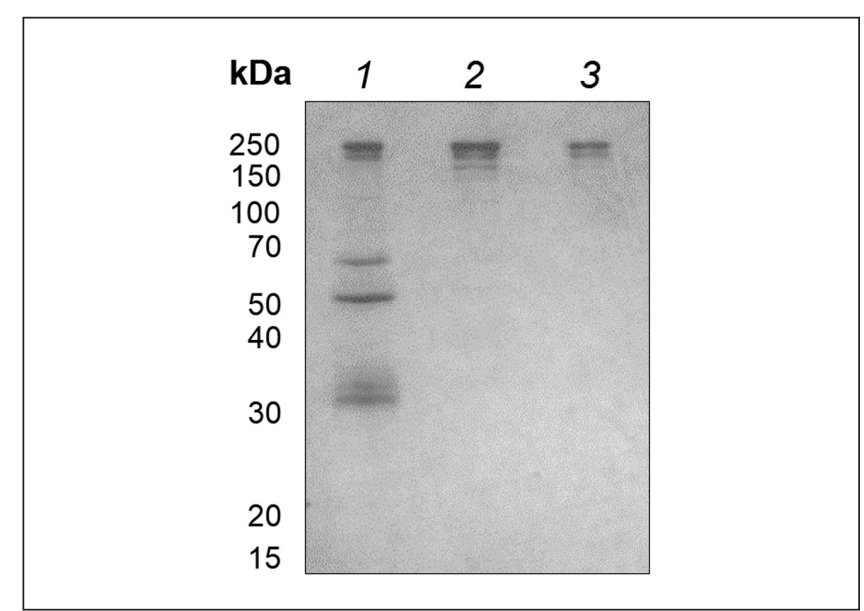

Fig. 1: Determination of IgY purity at different steps of isolation Representative analysis of IgY antibody purity by SDS PAGE (4-12\%, Tris-glycine) under non-reducing conditions followed by Coomassie blue staining ( $1 \mu \mathrm{g}$ IgY/lane). Lane 1: primary supernatant of the egg yolk protein fraction (after precipitation with 3.5\% PEG 6000), lane 2: final IgY isolate, and lane 3: IgY purified by gel filtration on a Sephadex G-100. 
(Fig. 2B). In contrast, for the KLH-CA 15-3(1066-1085)-immunized hens, the response was irregular with the highest peak at the $9^{\text {th }}$ week after the initial immunization, and the humoral immune response decreased with time. Furthermore, their avidity was notably lower in comparison with other groups (Fig. 2C).

In the hens that were given the CA 15-3(1066-1085) epitope as a BSA conjugate, production of IgY antibodies was observed by the $5^{\text {th }}$ week after the initial immunization and reached the maximum level at the $10^{\text {th }}$ week (Fig. 2D). However, both the overall reactivity of the specific IgY antibodies with the target fragment and their avidity were distinctly higher than those of the epitopespecific IgY antibodies raised against KLH-CA 15-3(1066-1085).

\subsection{Antibody titer and antigen detection limit}

The titer of antigen-specific IgY antibodies was $0.025 \mu \mathrm{g} / \mathrm{ml}$ (Fig. $3 \mathrm{~A}$ ) for the anti-CA $15-3$ antibodies and $0.1 \mu \mathrm{g} / \mathrm{ml}$ for the anti-CA 15-3(1085-1103) (Fig. 3B). Interestingly, a difference was noticed for the anti-CA 15-3(1066-1085) IgY antibodies; the titer depended on the carrier protein that was used. Thus, the titer was $2.5 \mu \mathrm{g} /$ $\mathrm{ml}$ or $0.5 \mu \mathrm{g} / \mathrm{ml}$ for the KLH or BSA conjugates, respectively (Fig. $3 \mathrm{C}$ ). The antigen detection limit was $2.5 \mathrm{ng} / \mathrm{ml}$ (which is equivalent to $0.07 \mathrm{U} / \mathrm{ml}$ ) of CA $15-3$ protein (Fig. $4 \mathrm{~A}$ ) and $1 \mathrm{ng} / \mathrm{ml}$ of CA
15-3(1085-1103) epitope (BSA-conjugate used for the analysis, Fig. 4B). The detection limit of the CA 15-3(1066-1085) epitope was $10 \mathrm{ng} / \mathrm{ml}$ and $25 \mathrm{ng} / \mathrm{ml}$ using antibodies raised by immunization with the BSA and KLH conjugates, respectively (Fig. 4C).

\subsection{Comparison of reactivity of anti-CA 15-3 avian IgY and mammalian IgG antibodies}

The reactivity of our generated anti-CA 15-3 IgY antibody with native antigen was compared to commercially available mouse monoclonal anti-CA 15-3 IgG antibodies (clone A and B) using an indirect ELISA assay. The reactivity of anti-CA 15-3 IgY antibodies was comparable to the reactivity of the mouse monoclonal IgG antibody (clone A), which displayed EI values of 30 and 34.4, respectively. Clone B showed significantly lower activity $(\mathrm{EI}=5.6)$, and the detection limit was greater by an order of magnitude (100 $\mathrm{ng} / \mathrm{ml}(2.8 \mathrm{U} / \mathrm{ml})$, Fig. 5A). Similar results to those obtained in the ELISA assay were observed in the dot blot analysis. The comparison revealed an equal CA 15-3 detection limit for the specific IgY antibody and clone A of the mouse monoclonal anti-CA 15-3 IgG antibody ( $1 \mathrm{ng}$ ). For clone B, the CA 15-3 detection limit was greater by one order of magnitude, which is in agreement with the ELISA results (Fig. 5B).
A

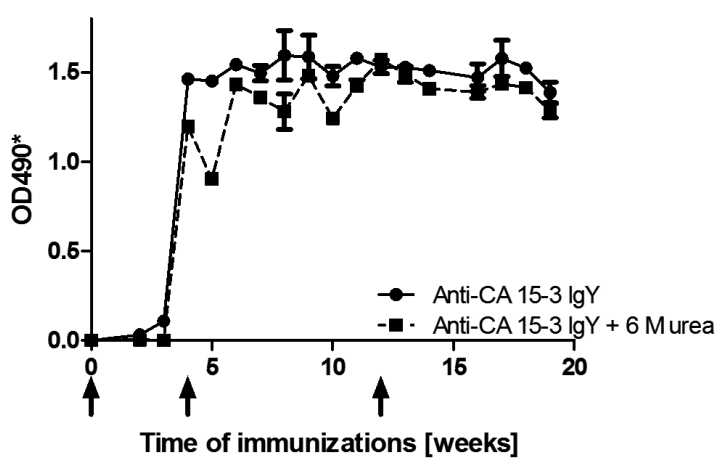

C

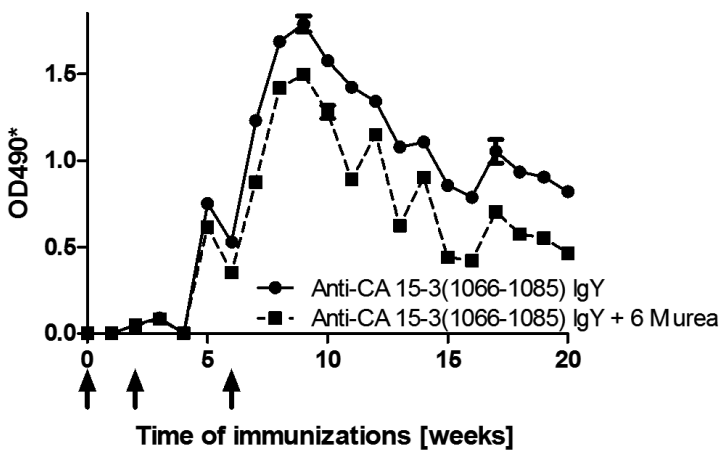

B

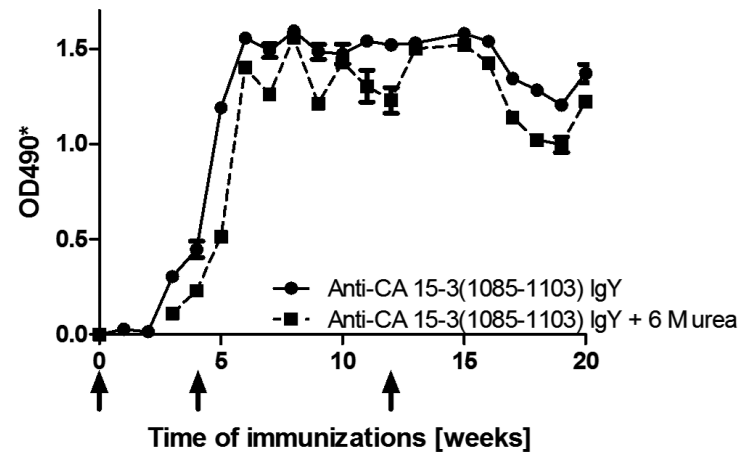

D

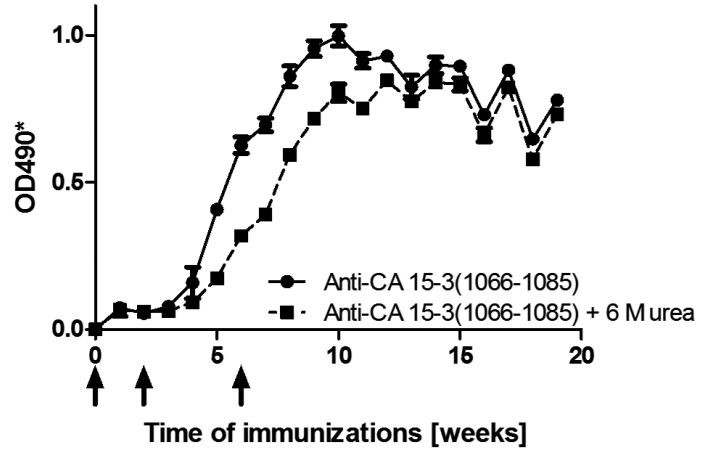

Fig. 2: Production of specific IgY antibodies during the course of immunization

The antigen-specific IgY antibody production (-- ---) by hens immunized with native CA 15-3 protein (A), KLH-CA 15-3(1085-1103) (B), KLH-CA 15-3(1066-1085) (C), and BSA-CA 15-3(1066-1085) (D) with avidity maturation (-- ---). The plates were coated with $500 \mathrm{ng} / \mathrm{ml}$ of target antigen and incubated with specific or control IgY antibodies (1:100). Rabbit anti-lgY-HRP conjugate was used in a 1:5000 dilution. The results are expressed as the OD490* values obtained after normalization to the background absorbance by subtraction of the values obtained for the control antibodies. Each point represents the mean $\pm S E M$ of experiments performed in duplicate. 

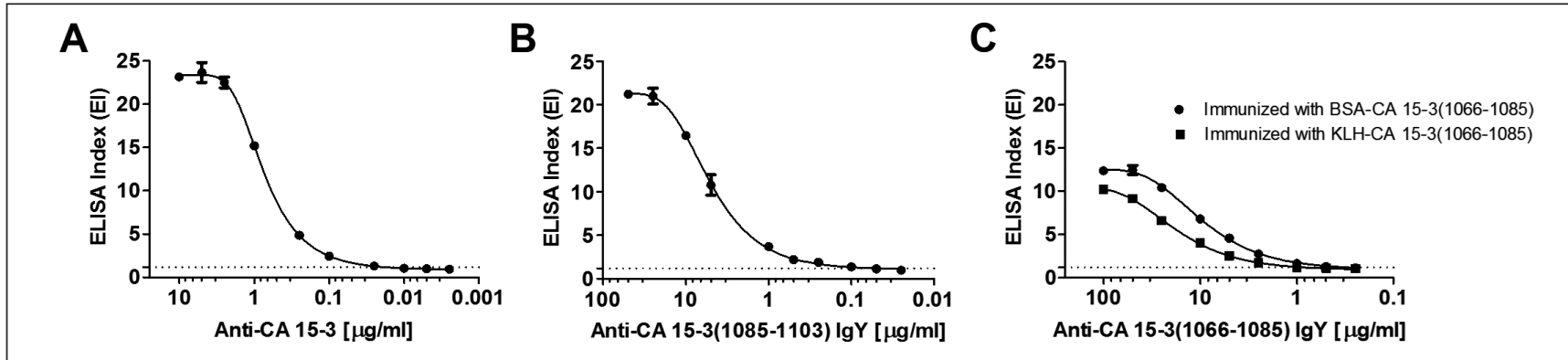

Fig. 3: Antigen-specific IgY antibody titer determined by indirect ELISA

Plates were coated with $500 \mathrm{ng} / \mathrm{ml}$ target antigen: CA 15-3 protein (A), BSA-CA 15-3(1085-1103) (B), and CA 15-3(1066-1085)-KLH

(----), or -BSA (----) conjugate $(\mathrm{C})$, then incubated with a serial dilution of antigen-specific or control antibodies within the following range of concentrations: (A) 10-0.0025 $\mu \mathrm{g} / \mathrm{ml}$ anti-CA 15-3 IgY antibody; (B) 50-0.025 $\mu \mathrm{g} / \mathrm{ml}$ anti-CA 15-3(1085-1103) IgY antibody;

and (C) 100-0.25 $\mathrm{gg} / \mathrm{ml}$ anti-CA 15-3(1066-1085) IgY antibody generated after immunization with BSA-CA 15-3(1066-1085) (--0--) or

KLH-CA 15-3(1066-1085) (--口--). The results are presented as an ELISA Index (EI), where EI = OD sample/OD control. Each point represents the mean \pm SEM of experiments performed in duplicate.

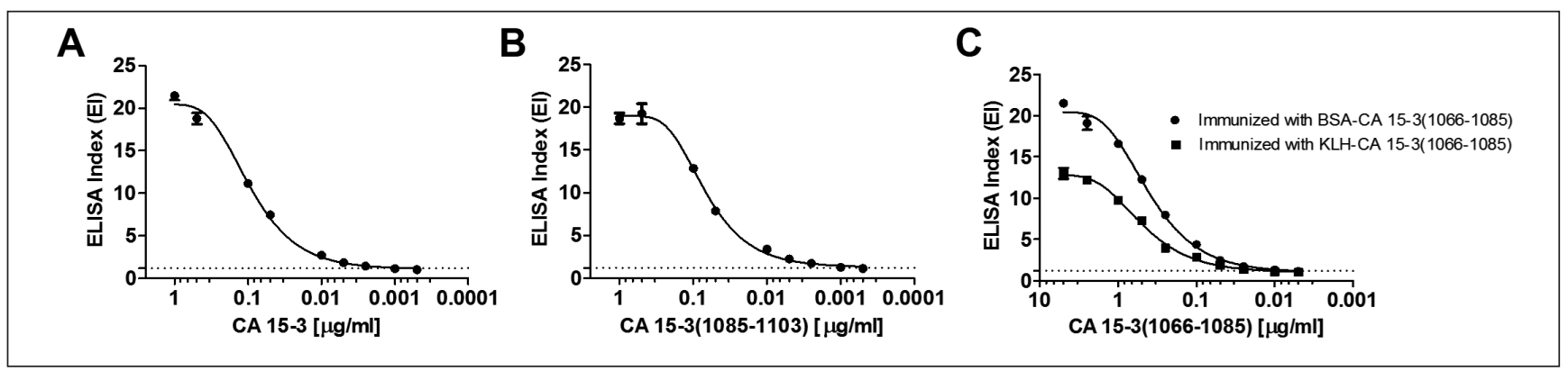

Fig. 4: Antigen detection limit determined by indirect ELISA

Plates coated with serial dilutions of antigen within the range of $1 \mu \mathrm{g} / \mathrm{ml}-0.5 \mathrm{ng} / \mathrm{ml}$ for CA 15-3 (A) and BSA-CA 15-3(1085-1103) (B), or $5 \mu \mathrm{g} / \mathrm{ml} \mathrm{-} 5 \mathrm{ng} / \mathrm{ml}$ for KLH-CA 15-3(1066-1085) (----) and BSA-CA 15-3(1066-1085) (-----) (C) were incubated with $10 \mu \mathrm{g} / \mathrm{ml}$ of antiCA 15-3 lgY antibody (A), anti-CA 15-3(1085-1103) IgY antibody (B), or $25 \mu \mathrm{g} / \mathrm{ml}$ of anti-CA 15-3(1066-1085) IgY antibody (C). Each point represents the mean \pm SEM of experiments performed in duplicate.

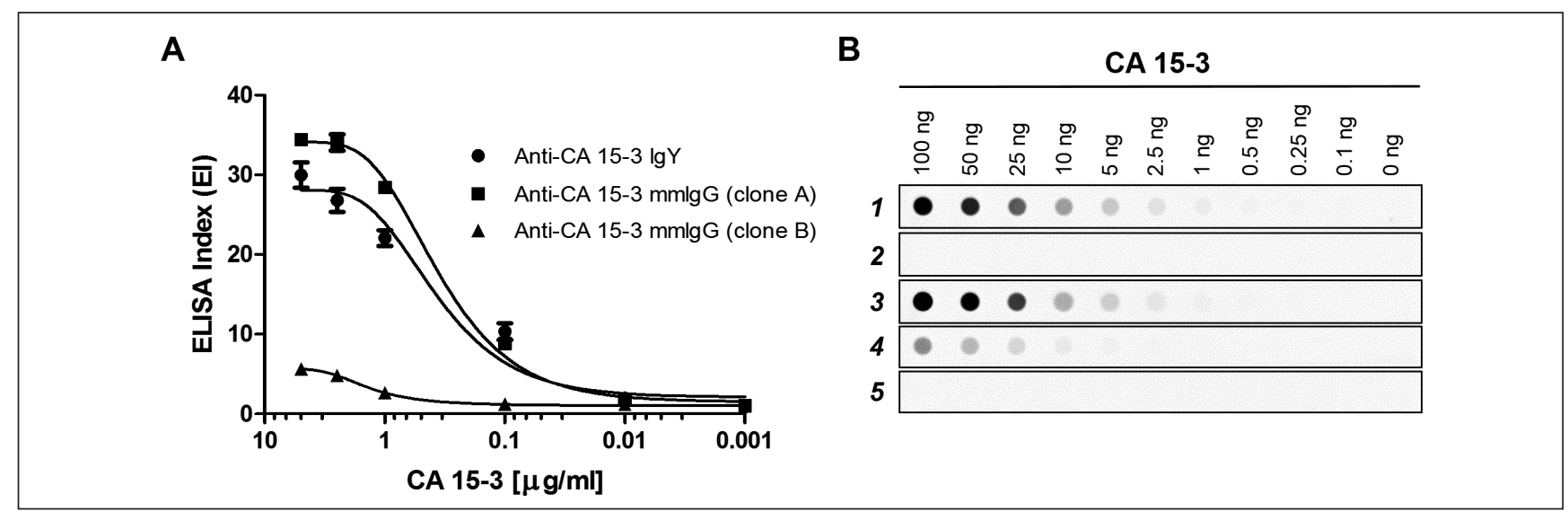

Fig. 5: Reactivity of the anti-CA 15-3 IgY antibody in comparison with mouse monoclonal anti-CA 15-3 IgG

For the ELISA assay (A), CA 15-3 protein was used in a concentration range of $5 \mu \mathrm{g} / \mathrm{ml}-1 \mathrm{ng} / \mathrm{ml}$, followed by incubation with the tested antibodies at $2 \mu \mathrm{g} / \mathrm{ml}$ : anti-CA 15-3 lgY antibody (----), mouse monoclonal anti-CA 15-3 lgG clone A (-- --), mouse monoclonal anti-CA 15-3 IgG clone B (--A--), control IgY, and control IgG. The secondary rabbit anti-IgY-HRP or rabbit anti-mouse IgG-HRP antibody was used at a 1:2500. Each point represents the mean \pm SEM of experiments performed in duplicate. For dot blot (B), $100 \mathrm{ng}-0.1 \mathrm{ng}$ of antigen was used. After the blocking step, the strips were incubated with the tested antibodies (2 $\mu \mathrm{g} / \mathrm{ml}): 1$ ) anti-CA 15-3 lgY; 2) control lgY; 3) mouse monoclonal anti-CA 15-3 IgG (clone A); 4) mouse monoclonal anti-CA 15-3 lgG (clone B); 5) control lgG prepared in 0.5\% skim milk/PBST. After incubation with the HRP-conjugates (rabbit anti-IgY-HRP $(1: 10,000)$ or rabbit anti-mouse IgG-HRP antibody (1:2500)), chemiluminescent peroxidase substrate was added, and the signals were visualized using an imaging system equipped with a CCD camera. 


\subsection{CA 15-3 cross-reactivity with fragment-specific IgY antibodies}

The analysis of the IgY antibody cross-reactivity with the native CA 15-3 protein revealed that the anti-CA 15-3(1085-1103) IgY antibody displayed an EI value of 2.34 and that the CA 15-3 antigen detection limit was $0.25 \mu \mathrm{g} / \mathrm{ml}(7.0 \mathrm{U} / \mathrm{ml})$ (Fig. 6). The antibodies isolated from the egg yolks of hens challenged with BSA-CA 15-3(1066-1085) showed an EI value of 5.15 and a detection limit of $0.05 \mu \mathrm{g} / \mathrm{ml}(1.4 \mathrm{U} / \mathrm{ml})$ (Fig. 6A). The dot blot analysis of the epitope-specific $\operatorname{IgY}$ antibody cross-reactivity showed a 50 ng detection limit for the native CA 15-3 protein, as determined by anti-CA 15-3(1085-1103) as well as anti-CA 15-3(1066-1085) IgY antibodies (raised with BSA conjugate;
Fig. 6B). Surprisingly, the $\operatorname{Ig} Y$ antibodies directed against the same peptidyl epitope but raised by immunization with the KLH conjugate did not show any cross-reactivity with the native CA 15-3 protein.

\subsection{CA 15-3 antigen detection by sandwich ELISA}

To demonstrate the potential diagnostic application of the generated anti-CA 15-3 IgY antibody, a sandwich ELISA assay was developed using mouse monoclonal anti-CA 15-3 IgG as a capture antibody and anti-CA 15-3 IgY as a secondary antibody. Using the conditions of our assay, the CA 15-3 protein detection limit was $1 \mathrm{ng} / \mathrm{ml}(0.028 \mathrm{U} / \mathrm{ml})$, and the linear range of detection was $1.25-0.01 \mathrm{U} / \mathrm{ml}$ (Fig. 7).

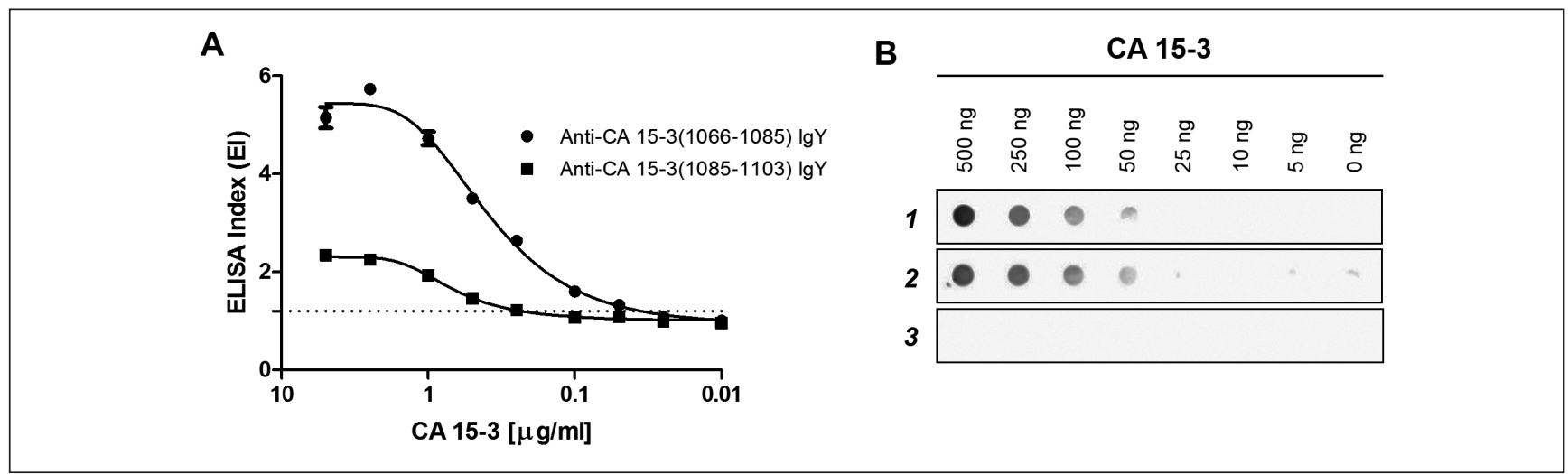

Fig. 6: The cross-reactivity of epitope-specific IgY antibodies with native CA 15-3 protein

For ELISA (A), the plate was coated with CA $15-3$ protein in a concentration range of $5 \mu \mathrm{g} / \mathrm{ml}-10 \mathrm{ng} / \mathrm{ml}$ and incubated with $50 \mu \mathrm{g} / \mathrm{ml}$ anti-CA 15-3(1066-1085) IgY antibody (--•--) generated with BSA-CA 15-3(1066-1085) or anti-CA 15-3(1085-1103) IgY antibody (-- ---) followed by incubation with rabbit anti-IgY IgG-HRP (1:5000). Each point represents the mean $\pm S E M$ of experiments performed in duplicate. For the dot blot experiment (B), the membrane was coated with $500 \mathrm{ng}-5 \mathrm{ng}$ native CA $15-3$ protein. The membrane strips were blocked and incubated with epitope-specific and control IgY antibodies at $100 \mu \mathrm{g} / \mathrm{ml}$ : 1) anti-CA 15-3(1066-1085) IgY; 2) anti-CA 15-3(1085-1103); 3) control lgY. The rabbit anti-IgY-HRP conjugate was used at 1:10,000.

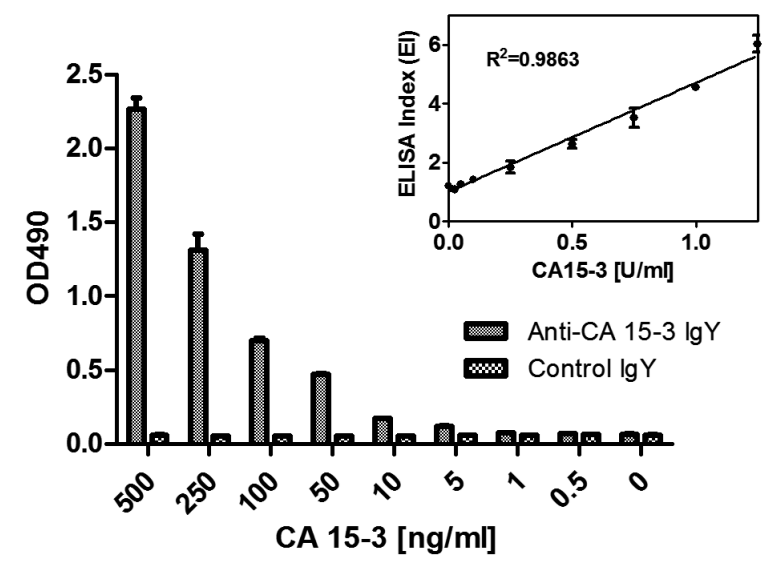

Fig. 7: Highly sensitive assay for CA 15-3 detection

The sandwich ELISA for CA 15-3 detection was developed using mouse monoclonal anti-CA 15-3 IgG (clone A) as a capture antibody and anti-CA 15-3 lgY as a detecting antibody. The plate was coated with $2 \mu \mathrm{g} / \mathrm{ml}$ of mouse monoclonal anti-CA $15-3 \mathrm{lgG}$ and subsequently incubated with a serial dilution of CA $15-3$ protein $(500 \mathrm{ng} / \mathrm{ml}-0.5 \mathrm{ng} / \mathrm{ml})$. Anti-CA $15-3 \mathrm{lg} Y$ and control lgY antibodies were used at $10 \mu \mathrm{g} / \mathrm{ml}$ and followed by incubation with rabbit anti-lgY-HRP (1:5000). The signal was developed using OPD as a chromogenic peroxidase substrate. The assay was linear within the concentration range of 1.25-0.01 U/ml. Each point represents the mean \pm SEM of experiments performed in duplicate. 


\section{Discussion}

Although the international recommendations vary with respect to the CA 15-3 antigen, many diagnostic guidelines support the application of the CA 15-3 as the breast cancer marker used for monitoring therapy effectiveness and, in many cases, for postoperative surveillance in asymptomatic patients (Duffy, 2006; Duffy et al., 2010). This limited applicability is a consequence of both the low specificity of CA 15-3 (an elevation in its level may be observed in other carcinomas) and the limited sensitivity for early-stage breast cancer. Nevertheless, together with CEA, CA $15-3$ is the most investigated and used serum marker in breast cancer diagnostics.

Herein, we present the development of IgY antibodies generated with native CA 15-3 protein as well two of its epitope fragments, CA 15-3(1066-1085) and CA 15-3(1085-1103), which were isolated from egg yolk with an average yield of $90 \mathrm{mg}$ per yolk. According to literature reports, up to $10 \%$ of the antibodies in the yolk can be antigen-specific (Da Silva and Tambourgi, 2010). However, our observations indicate that the average amount of antigen-specific $\operatorname{IgY}$ in the egg yolk from immunized hens does not exceed 5\% (data not shown). Nevertheless, even considering the $4.5 \mathrm{mg}$ of antigen-specific IgY antibodies per single egg, the obtained amount is equivalent to the amount of rabbit $\mathrm{IgG}$ antibodies that could be obtained from approximately $20 \mathrm{ml}$ of rabbit blood (Narat, 2003). Therefore, the utilization of avian IgY antibodies represents considerable economical as well as ethical advantages over mammalian IgG antibody production.

The evolutionary distance between mammals and birds is sufficient to evoke an avian immune response against highly conserved mammalian proteins, which is difficult or rather impossible when different mammalian species are immunized. The antigen-specific immune response of hens, as manifested by the production of IgY antibodies, was observed for all antigens used in this study. The CA 15-3 detection limit determined using the IgY antibody directed against the native antigen by indirect ELI$\mathrm{SA}$ was $2.5 \mathrm{ng} / \mathrm{ml}$ (0.07 U/ml; Fig. 4). Moreover, a comparison of the anti-CA 15-3 IgY antibody and mouse monoclonal antiCA 15-3 IgG (clone A) revealed similar reactivity, displaying EI values of 30 and 34.4, respectively; in contrast, clone B showed a significantly lower reactivity and antigen detection limit (Fig. 5). The polyclonal $\operatorname{IgY}$ antibodies used in this study were not subjected to any affinity purification to enrich the sample with an antigen-specific fraction.

The potential of epitope-specific antibodies is determined by their ability to recognize the native antigen from which the epitopes originated. Antibodies generated using both of the selected CA 15-3 epitopes were able to recognize the native protein; however, the CA 15-3 detection limit for the anti-CA 15-3(10661085) IgY antibodies (generated using BSA conjugate) was 5-fold lower than for the anti-CA 15-3(1085-1103) (Fig. 6A). Nevertheless, the recognition potential for both generated epitope-specific anti-CA 15-3 IgY antibodies was sufficient for CA 15-3 detection, particularly when the reference range of serum CA 15-3 cut-off value $(25-40 \mathrm{U} / \mathrm{ml})$ is considered. Additionally, the potency of the cross-reactive recognition of CA $15-3$ by the epitope-specific IgY antibodies could be further improved by affinity purification.
Immunochemical analysis revealed some differences in the hen immune response after immunization with the KLH-CA 153(1085-1103) and BSA-CA 15-3(1066-1085) conjugates. In general, the anti-CA 15-3(1085-1103) IgY antibody response arose earlier in the course of immunization, and the overall reactivity (titer, avidity, detection limit) was higher than observed for anti-CA 15-3(1066-1085). One explanation could be the different peptide-carrier molar ratio for the KLH and BSA conjugates used for immunization. However, immunization with BSA-CA 15-3(1066-1085) improved the epitope-specific reactivity of the generated IgY antibody and, more importantly, changing the carrier protein from $\mathrm{KLH}$ to BSA resulted in the development of cross-reactive IgY antibodies. These observations suggest that the CA 15-3(1066-1085) epitope is less immunogenic than the second selected epitope of the CA 15-3 protein; however, the carrier effect influencing the conformational state of the peptidyl epitope could be considered. The carrier effect was previously observed by Karle et al. for epitope-specific mouse IgG targeting the HIV-1 gp120 protein (Karle et al., 2003).

Commercially available CA 15-3 assays are based on mammalian anti-CA 15-3 antibodies and are usually used in the form of sandwich ELISA. The diagnostic potential of the generated antiCA 15-3 IgY antibody was examined by developing a sandwich ELISA based on mouse monoclonal IgGs for antigen capturing and IgYs as detecting antibodies. The resulting detection limit of $0.028 \mathrm{U} / \mathrm{ml}$ for CA $15-3$ and the linearity range between 1.25 $0.01 \mathrm{U} / \mathrm{ml}$ support the potential of such an assay for serum CA 15-3 detection (Fig. 7). Additionally, considering all aspects of IgY antibody production, including the high amount of antibody obtained from a single egg at a cost which usually does not exceed $1 \$$ per milligram specific polyclonal IgY and the ethical side of IgY technology (reduced number of injections, no need for animal bleeding since antibodies are isolated from egg yolk, and long lasting immune response to a given antigen), IgY represent an interesting alternative to commonly used mammalian immunoglobulins in diagnostic applications.

\section{References}

Al-Haddad, S., Zhang, Z., Leygue, E., et al. (1999). Psoriasin (S100A7) expression and invasive breast cancer. Am J Pathol 155, 2057-2066.

American Cancer Society (2011). Global Cancer Facts \& Figures. $2^{\text {nd }}$ edition. Atlanta, USA: American Cancer Society. http:// www.cancer.org/research/cancerfactsfigures/globalcancerfacts figures/global-facts-figures-2nd-ed

Arnold, K., Bordoli, L., Kopp, J., et al. (2006). The SWISS-MODEL Workspace: A web-based environment for protein structure homology modeling. Bioinformatics 22, 195-201.

Cheung, K. L., Graves, C. R., and Robertson, J. F. (2009). Tumour marker measurements in the diagnosis and monitoring of breast cancer. Cancer Treat Rev 26,91-102.

Da Silva, W. D. and Tambourgi, D. V. (2010). IgY: A promising antibody for use in immunodiagnostic and in immunotherapy. Vet Immunol Immunopathol 135, 173-180.

Deguchi, T., Tanemura, M., Miyoshi, E., et al. (2010). Increased immunogenicity of tumor-associated antigen, mucin 1 , engi- 
neered to express alpha-gal epitopes: a novel approach to immunotherapy in pancreatic cancer. Cancer Res 70, 5259-5269.

Duffy, M. J. (2006). Serum tumor markers in breast cancer: are they of clinical value? Clin Chem 52, 345-351.

Duffy, M. J., Evoy, D., and McDermott, E. W. (2010). CA 15-3: uses and limitation as a biomarker for breast cancer. Clin Chim Acta 411, 1869-1874.

Esslimani-Sahla, M., Kramar, A., Simony-Lafontaine, J., et al. (2005). Increased estrogen receptor betacx expression during mammary carcinogenesis. Clin Cancer Res 11,3170-3174.

Grebenschikov, N., Geurts-Moespot, A., De Witte, H., et al. (1997). A sensitive and robust assay for urokinase and tissue-type plasminogen activators (uPA and tPA) and their inhibitor type I (PAI1) in breast tumor cytosols. Int J Biol Markers 12, 6-14.

Hanisch, F. G. and Müller, S. (2000). MUC1: the polymorphic appearance of a human mucin. Glycobiology 10, 439-449.

Hayes, D. F., Sekine, H., Ohno, T., et al. (1985). Use of a murine monoclonal antibody for detection of circulating plasma DF3 antigen levels in breast cancer patients. J Clin Invest 75, 16711678.

He, Q., Fornander, T., Johansson, H., et al. (2006). Thymidine kinase 1 in serum predicts increased risk of distant or loco-regional recurrence following surgery in patients with early breast cancer. Anticancer Res 26, 4753-4759.

Huang, Z. H., Tian, X. S., Li, R., et al. (2012). Elevated thymidine kinase 1 in serum following neoadjuvant chemotherapy predicts poor outcome for patients with locally advanced breast cancer. Exp Ther Med 3, 331-335.

Kallioniemi, O. P., Oksa, H., Aaran, R. K., et al. (1988). Serum CA 15-3 assay in the diagnosis and follow-up of breast cancer. $\mathrm{Br} \mathrm{J}$ Cancer 58, 213-215.

Karle, S., Nishiyama, Y., Taguchi, H., et al. (2003). Carrier-dependent specificity of antibodies to a conserved peptide determinant of gp120. Vaccine 21, 1213-1218.

Kilkenny, C., Browne, W. J., Cuthill, I. C., et al. (2010). Improving bioscience research reporting: The ARRIVE guidelines for reporting animal research. PLOS Biology 8, e1000412.

Klee, G. G. and Schreiber, W. E. (2004). MUC1 gene-derived glycoprotein assays for monitoring breast cancer (CA 15-3, CA 27.29, BR): are they measuring the same antigen? Arch Pathol Lab Med 128, 1131-1135.

Li, L., Li, C., Sarkar, S., et al. (2012). DelPhi: a comprehensive suite for DelPhi software and associated resources. BMC Biophys. 5,9 .

Macao, B., Johansson, D. G., Hansson, G. C., et al. (2006). Autoproteolysis coupled to protein folding in the SEA domain of the membrane-bound MUC1 mucin. Nat Struct Mol Biol 13, 71-76.

Michaelson, J. S., Silverstein, M., Sgroi, D., et al. (2003). The effect of tumor size and lymph node status on breast carcinoma lethality. Cancer 98, 2133-2143.

Muňoz, V. and Serrano, L. (1997). Development of the multiple sequence approximation within the AGADIR model of alphahelix formation: comparison with Zimm-Bragg and Lifson-Roig formalisms. Biopolymers 41, 495-509.

Narat, M. (2003). Production of antibodies in chickens. Food Technol Biotechnol 41, 259-267.
Nothacker, M., Duda, V., Hahn, M., et al. (2009). Early detection of breast cancer: benefits and risks of supplemental breast ultrasound in asymptomatic women with mammographically dense breast tissue. A systematic review. BMC Cancer 9, 335.

Polson, A., von Wechmar, B., and van Regenmortel, M. H. V. (1980). Isolation of viral IgY antibodies from yolks of immunized hens. Immunol Commun 9, 475-493.

Schade, R. and Hlinak, A. (1996). Egg yolk antibodies, state of the art and future prospects. ALTEX 13, 5-9.

Schade, R., Calzado, E. G., Sarmiento, R., et al. (2005). Chicken egg yolk antibodies (IgY-technology): a review of progress in production and use in research and human and veterinary medicine. Altern Lab Anim 33, 129-154.

Silva, D. A. O., Silva, N. M., Mineo, T. W. P., et al. (2002). Heterologous antibodies to evaluate the kinetics of the humoral immune response in dogs experimentally infected with Toxoplasma gondii RH strain. Vet Parasitol 107, 181-195.

Singh, R. and Bandyopadhyay, D. (2007). MUC1: a target molecule for cancer therapy. Cancer Biol Ther 6, 481-486.

Svendsen Bollen, L., Crowley, A., Stodulski, G., et al. (1996). Antibody production in rabbits and chickens immunized with human IgG. A comparison of titre and avidity development in rabbit serum, chicken serum and egg yolk using three different adjuvants. J Immunol Methods 191, 113-120.

Warr, G. W., Magor, K. E., and Higgins, D. A. (1995). IgY: clues to the origins of modern antibodies. Immunol Today 16, 392-398.

Xiao, Y., Gao, X., Taratula, O., et al. (2009). Anti-HER2 IgY antibody-functionalized single-walled carbon nanotubes for detection and selective destruction of breast cancer cells. BMC Cancer 9,351 .

\section{Acknowledgments}

This work was supported by a Polish research funding agency, the National Center for Research and Development (LIDER/08/90/1-1/09/NCBiR/2010). The funder had no role in the study design, data collection and analysis, decision to publish, or preparation of the manuscript. This paper was cofinanced by the European Union as part of the European Social Fund. The authors would like to thank Sylwia Świątek and Agnieszka Bartnicka for their excellent technical assistance. MS, RG and JO are thankful to Wroclaw University of Technology for support (Statute Funds S30134/Z0313).

\section{Correspondence to}

Marcin Sieńczyk, PhD

Wroclaw University of Technology

Faculty of Chemistry

Division of Medicinal Chemistry and Microbiology

Wybrzeze Wyspianskiego 29, Building A2

50-370 Wroclaw

Poland

Phone: +48 713202439

Fax: +48 713202427

e-mail: Marcin.Sienczyk@pwr.wroc.pl 